\title{
Exploring Hegemonic Masculinity in Amandeep Sandhu's Roll of Honour
}

\author{
Jaspreet Singh \\ Research Scholar, Department of English, School of Humanities and Languages \\ Central University of Himachal Pradesh, Dharamshala, Himachal Pradesh, India
}

\section{OPEN ACCESS}

Volume: 8

Issue: 2

Month: March

Year: 2020

P-ISSN: 2320-2645

E-ISSN: 2582-3531

Received: 11.01.2020

Accepted: 15.02 .2020

\begin{abstract}
Masculinity often associated with being strong, aggressive, powerful. Masculinity, as a social construct, plays a significant role in shaping the public-private behavior of men. The emerging field of studies on men has extensively dealt with the question of construction, practice, and variations of masculinity. Amandeep Sandhu's Roll of Honour (2012) underpins the constructed hegemonic masculinity through the resistance of subordinated masculinities. The text unravels the traumatic effects of the traditional notion of masculinity faced by the protagonist, Appu. The narrative contains implicit and explicit references to sexual abuse. Sexual abuse, especially targeting children, is not only physical and mental abuse but also a political act imposing masculinity. The present paper explores the recurrence of sexual abuse in the text as a method of constructing hegemonic masculinity and resistance to this abuse as the assertion and counter-hegemonic exercise of various kinds of subordinated masculinities. The paper focuses on unraveling the politics of domination and tracing the use of sexual abuse as a coercive political tool. Through the life of Appu, Sandhu delineates the various socio-political layers associated with sexual abuse, as well as the horrific trauma of victims and the aftermath of such incidents. The present paper engages with various forms of resistance by the characters who were prone to or victimized by sexual abuse at the hands of abusers.
\end{abstract}

Keywords: Masculinity, Sexuality, Sodomy, Abuse, Domination, Resistance.

Published: 01.03.2020

Citation:

Singh, Jaspreet.

"Exploring Hegemonic

Masculinity in Amandeep

Sandhu's Roll of

Honour." Shanlax

International Journal

of English, vol. 8, no. 2,

2020, pp. 1-6.

DOI:

https://doi.org/10.34293/

english.v8i2.1653

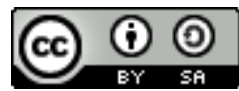

This work is licensed under a Creative Commons Attribution-

ShareAlike 4.0

International License

Masculinity, as a concept, has undergone a transformative shift with the evolution of gender studies. Applied into a dichotomous binary of masculine and feminine, masculinity was generally conceived as a homogenous social construct in the beginning. Advancement and recognition of LGBT theoretical concepts and flux of studies on the social construction of gender roles have reformed masculinity into a site where contestations of heterogeneous ideas taking place. Sallie Westwood argues that masculinity exists in a "plurality of forms," and there is "not fixed set of attributes" that can be labeled as masculinity. Thus masculinity as a concept has to be considered "as unstable and multiple, as decentred and subject to changing contexts, in a constant play of reproduction and innovation" (Westwood 24). This multiplicity of masculinity is also asserted by Maritain Mac, a Ghaill in Understanding Masculinities (1996) he argues that: ... we need to move away from categorical theories that emphasize that gender/sexual relations are shaped by a single overarching factor. Rather, they suggest that these relations are multidimensional and differentially experienced and responded to within specific historical contexts and social locations. (1)

For recognizing and comprehending the existence, resistance, and relationship between various kinds of masculinities, R.W. Connell's concept of hegemonic masculinity becomes a crucial point. As Wolpe argues, "differentiated forms of male power can only be accounted for by analysis which takes into consideration the specific conditions that give rise to these situations" (11). 
An important aspect of this more complex view of the multiplicity of masculinities is a critical focus on the multidimensional social subject, involving an exploration of interactions and intersections within and between different sets of social relations (Ghaill 1). In the present paper, while discussing the idea of hegemonic masculinity, I will divulge how the narrative of Roll of Honour constructs multiple masculinities and position them relationally to other men, women, and femininity in society? How the normative myths and dominant stereotypes of patriarchy aids or limit constructions of masculinities? How such constructed masculinity of hegemonic nature paves the way for abuse and oppression on the different masculinities? How the existence and practice of multiple masculinities formulate a counter-hegemonic masculinity basis?

The idea of hegemonic masculinity was coined by R. W. in Gender and Power: Society, the Person and Sexual Politics (1987). According to Connell, there is a hierarchy of versions of masculinity. The hierarchy originates from the factors like complexities of relationships, ethnic differences, generational differences, class patterns, etc. An Amalgamation of various factors finds expression in a multiplicity of construction of masculinities (Connell 181). Thus the concept of masculinity has to be evaluated, comprehended as a heterogeneous entity. In Gender and Power (1987), Connell argues, hegemonic masculinity is always constructed about various subordinated masculinities as well as about women.

Further, the functioning of a patriarchal social order depends on the interplay between different forms of masculinity (Connell 183). Connell explains in hegemonic masculinity, 'hegemony' refers to "a social ascendency achieved in a play of social forces that extends beyond contests of brute power into an organization of private life and cultural process" (183). This ascendency is embedded in social, cultural, religious doctrines, practices laws, socialpolitical, economic structures.

There is a close connection between the ascendency based on force and ascendency achieved through social and cultural conditioning. As Connell notes, physical and economic violence backs up a dominant cultural pattern or ideologies justifies acts, policies of the physical power holders. This analysis depicts a close connection between hegemonic masculinity and patriarchal violence (Connell 184). This close connection is quite evident in Roll of Honour as the text depicts multiple incidents where physical violence functions as a tool, used to form consent.

Connell's deliberations of the nature of hegemony become vital regarding the presence of multiple masculinities in Roll of Honour. While formulating the concept of hegemonic masculinity, Connell's recognition of the existence of counterhegemonic practices opens the space for expounding upon the dialectic nature of multiple masculinities. As for Connell, hegemony not refers to absolute cultural domination or obliterations of alternatives. Rather it is a "state of play" achieved within the balance of forces. Thus here, hegemony refers to the subordination of other groups, types, or patterns to the dominated one, not the elimination of these. Thus this formulation provides the space for considering hegemonic masculinity as a site of contestation inheriting dynamic nature.

Masculinity is not a fixed entity embedded in the body or personality traits of individuals. Masculinities are configurations of practice that are accomplished in social action and, therefore, can differ according to the gender relations in a particular social setting (Connell 836). Tracing historically, masculinity does not have a linear model but is constantly reconstructed about social, political, and cultural developments. Therefore, masculinities are contested terrain and subject to instability and change (Westwood 25). The flexibility of masculinity can be traced in changing perceptions of Appu, the protagonist. The fluidity further explains the varied responses to the conflicting situations in the text. Thus violence and other noxious practices are not always the defining characteristics since hegemony has numerous configurations. As Wetherell and Edley (1999) observe, one of the most effective ways of "being a man" in certain local contexts may be to demonstrate one's distance from regional hegemonic masculinity (840). In Roll of Honour existence of masculinities is layered and complicated. They tend to be similar at certain points, different at others, and reflect and refract against one an-other in arbitrary 
and premeditated ways. Complicated interaction of various masculinities becomes the contested site from where through dominance, hegemonic masculinity emerges. In The Men and the Boys (2000), R.W. Connell notes that "different masculinities do not sit side-by-side like dishes on a smorgas bord. There are definite social relations between them ... there are relations of hierarchy, for some masculinities are dominant while others are marginalized"

(10). James Messerschmidt, in his essay "Masculinities and Femicide," argues that:

Connell emphasized that hegemonic and nonhegemonic masculinities are all subject to change because they come into existence in specific settings and under particular situations. Moreover, in the case of the former, there often exists a struggle for hegemony whereby older versions may be replaced by newer ones. The notion of hegemonic masculinity and nonhegemonic masculinities then opened up the possibility of change towards the abolition of gender inequalities and the creation of more egalitarian gender relations. (72)

It is important to emphasize that not all masculinities are hegemonic and always legitimate unequal gender relations. Power is never distributed equally. Messerschmidt in Masculinities in the Making: From the Local to the Global (2016) refers to positive masculinities in this sense to indicate masculinities that do not legitimate unequal gender relations between men and women, masculinity and femininity, and amongst masculinities (39). Thus the recognition of hegemonic masculinities is bundled with the acceptance of multiplicity of masculinities.

The politics of constructing hegemonic masculinity aims at limiting, dehumanize, ostracizing the alternatives. As Connell argues:

Hegemonic masculinity is constructed about women and subordinated masculinities... achieving hegemony may consist precisely of preventing alternatives from gaining cultural definition and recognition as alternatives. Confining them to ghettos, to privacy, to unconsciousness. (186)

The role of physical violence and domination becomes important for attaining the consent or negating the alternative voices contesting hegemonic masculinity. Child sexual abuse can also be seen used as a tool of domination over the marginalized masculinities in the conflicting interplay of various kinds of masculinities. Child sexual abuse is one of the most horrific experience for the victim. It is not only related to sexuality but also has a socialpolitical paradigm of power. Lyn Yonack, defining sexual abuse, says, “... the motivation stems from the perpetrator's need for dominance and control". According to her, "sex is the tool used to gain power over another person" (Yonack 1). Stephan J. Rossetti argues, "Child sexual abuse is as much a crime of power as it is a crime of sexuality" (Rossetti 685). Rossetti further argues that "Child molestation can be sustained only in an atmosphere of silence and collusion" (Rossetti 686). Rossetti discussing child sexual abuse as an "abuse of power" observes, "the victim's harm is two-fold. First, their sexuality can be traumatized" and the second is "an ingrained sense of powerlessness." He argues, "Perpetrators abuse their position positions of power and unconsciously instill in [the] victim a sense of powerlessness. They often carry this feeling of powerlessness into adulthood" (Rossetti, 684).

Thus sexual abuse further causes feelings of fear and shame in the conscious of victims. To come out of the trauma of sexual abuse, victims need the courage to shed fears of domination by the perpetrator and also the social fear of being disrespected in society. Therefor the act of speaking about the experienced sexual abuse becomes an emancipatory political act. As Chutima Pragatwutisaran in his article "The Politics of Discourse in Sexual Abuse Narratives," opines that a victim needs to go against a social injunction which forces the victim into silence, for telling personal social experience. Thus speaking about a private issue turns out to be politically significant (Pragatwutisaran 40).

Sandhu in Roll of Honour depicts sexual abuse as an act with political consideration of domination, oppression, and marginalization. The narrator discusses in detail how sexual abuse at school was used by the powerful against weaker students, juniors, etc. The act of sodomy at school serves as a method to asserting power over the abused individual. The abused ones at school are called names such as "kaccha," "gaandu," etc. (89). 
These derogatory terms become the instrument of ideological construction for negating the dissenting masculine traits. Sexual abuse, on the one hand, leaves vicious effects on the victim. On the other, it holds social-political implications in-depth also. Sexual abuse of the female members of the defeated tribe, community, group was a common practice in the barbaric era of various societies. Even in modern times, the reports of alleged sexual abuse of women belonging to the families of rebels by securities forces of various nations surface from time to time. While defining sexual abuse Shekhar Sheshadri outlines the use of sexual abuse a tool of domination, she argues:

The age-old practice of the use of rape as a weapon of war is another illustration of how sexual abuse is used by one party (or community) to establish power and domination over another, an example of sexual engagement in a nonconsensual context" (Sheshadri).

From the political paradigm of ruling powers to paradigm of domination and subjugation on individual levels, all include sexual abuse as a weapon to demoralize, to oppress the already marginalized sections in various binary setups.

Sexual abuse thus becomes a method of domination of the hegemonic masculinity. As Connell deliberates that important feature of hegemonic masculinity is that it is heterosexual, a key form of subordinated masculinity is homosexual. Conell elaborates:

This subordination involves both direct interactions and a kind of ideological warfare... these transactions are tied together by the contempt for homosexuality and homosexual men that is part of the ideological package of hegemonic sexuality. (186)

In the development of the concept of hegemonic masculinity, divisions among men- especially the exclusion and subordination of homosexual menwere quite central issues (Carrigan, Connell, and Lee 1985). The policing of heterosexuality has been a major theme in discussions of hegemonic masculinity since then (837). To counter heterosexuality as normative, the acceptance and assertion of various sexual orientations depicted as an alternative to the hegemony. The narrator reveals how he feels pleased on getting an invite to an LGBT parade in Delhi; the narrator states his view on the issue:

I have believed that gays, lesbians, bisexuals, transgender, people and transsexuals are like anyone else, in fact, in many cases, sharper and more sensitive because they have had to survive the stigma that society has imposed upon them. (151)

This statement reveals his democratic and open-minded stand on the sexual orientation of an individual. Thus, here again, the narrator aims at blurring down or shattering the boundaries and their political usage to assert power over individuals with different sexual orientations. The narrator about his gay relationship with Gaurav writes, "G and I are not junior and senior, or powerless and powerful. We are equal," (156).

He further asserts on the assimilation of all individuals into the brotherhood despite various kinds of sexual orientations. For him walking in this LGBT, parade serves as a kind of Baptism as he finds himself released from the clutches of masculine subordination based on sexual orientation. He comments, "The rainbow seemed to be a cover under which each person was free to be, free to choose how to live, free to dream and to be accepted" (152).

The motto of that parade, "walk together to walk alone," has an important political undertone (152). To assert the difference in a free world without getting hatred and discrimination, all the individuals, groups, communities first have to come together to create such a society where such differences do not matter and do not affect individual's lives.

Apart from discussing sexual orientation, on another level, the act of sodomy is also equated with the treatment of Sikh by the hands of Congress-ruled central government. Akhad, Listen, and others who involved in sodomy and targets juniors, weaker classmates, are similar to Congress Government and asserts their power by penetrating forcefully by perpetuating violence. Same as the Congress has done by Operation Blue Star. Sikhs and Abused students find themselves in the same condition. They feel ashamed and helpless for not being able to protect themselves. Abdullah-Khan (2002) argues that male rape victims are neglected due to the powerful gender norms and stereotypes built-in' 
within institutions, which govern how both women and men are socialized. She argues that "Men have traditionally been expected to be strong and dominant and this expectation disallows them to be victims of a sexual offense that fundamentally threatens and challenges their sexuality and manliness" (12). Thus the act of sodomy or rape in the school consequently subordinates the victims of such acute sexual violence.

Hegemonic masculinity is perpetuated through the domination of other kinds of masculinities. In gendered politics, milieu concentration of social power in the hands of men results in a prerequisite of negation of various subordinate masculinities through the use of physical violence, domination, etc. Connell notes this tendency, he opines, because the concept of hegemonic masculinity is based on practice that permits men's collective dominance over women to continue, it is not surprising that in some contexts, hegemonic masculinity does refer to men's engaging in toxic practices -including physical violence- that stabilize gender dominance in a particular setting (Connell 840). It is a useful formulation, but I attempt to extend it further from its emphasis on a dichotomous gendered binary basis. Engagement in toxic masculinities against subordinate masculinities to push them into the peripheral zone is also a common practice. As Chutima argues, in the relationship of the abuser and the victim, the former imposes silence upon the latter. The injunction to silence is perpetrated and validated by public discourses such as taboos, social values, and legal systems. Such discursive forms discourage women from speaking out about their experience of sexual abuse by regarding the issue as unspeakable, inconceivable, or unimportant (Chutima). About the politics of abuse and power associated with this sexual abuse narrator comments:

No one said anything to the one who abused. The school culture placed a sense of manly awe around the abuser. The abuser was a hero, someone who had exercised power. The insults were for the abuser. (184).

The narrator further elaborates on how the discovery of abuse in such an environment becomes unsettling for the abused individual. The shame and disrespect that has been associated with being sodomized alienate the victimized individual further. Thus the narrator finds that this categorized balance needed to be challenged. The narrator, along with other abused characters, decides to take on the abuser by shaming them in public. The narrator tells us, "I decided to fight the bullies' false machismo... I knew I could not win through abuse, but I could win in being able to decide when I would unnerve the abuser" (212). He, Laadu, and Neer fight against the categorization of abused ones as gaandu - a derogatory for the victims of sodomy. Incident of Laadu's being naked and inviting Lalten to fuck him in public changes the whole politics associated with sodomy in school. This not only relieves Laadu from the abuse at the hands of Lalten through blackmailing but also changes the perspective of cadets. The narrator tells us, "the term 'gaandu' was no longer an abuse" (212). The survivor who breaks the silence plays the role of a resisting subject who refuses to be placed as powerless in the dominant discourse and constitutes his narrative to give voice to his experience. The survivor thus uses language as a strategic means of changing his subject position from victim to victor, from powerlessness to selfempowerment.

In parallel to this political and social environment of the country works in the same fashion. In the aftermath of 1984 and the assassination of Indira Gandhi, that same idiom was vague. Sikhs who were abused by Congress were also stand accused of separatism.

The narrator also equates the incidents of sodomy and incident related to his diary and the Operation Blue Star in Punjab. He comments:

The rape of the diary was like the army's attack on the Golden Temple...The Indian army attacked the Sikhs in a place where they were most vulnerable. A man had committed a crime on another man. (213)

The narrator finds the conduct of Congress government similar to the exploitative, abusive, dominating conduct of the abusers who sodomized other powerless or weak students. He further elaborates:

Operation Blue Star was an act of sodomy. Like my class, Sikhs lost what they believed was their entitlement. The Central government action and 
the riots had pushed the raped Sikhs into shame and confusion. The class's retaliation was similar to the way Sikhs no longer knew what to do next. (213)

The text depicts how closed discourse around sexuality in any particular society overtly increases the possibility of sexual abuse. The further shows the role of societal norms, society's attitude towards the victims plays an important role in such cases. Sexual abuse not merely an act of physical violence or dominance; it encompasses social-politicalcultural and psychological consequences. Thus Roll of Honour not only reveals the long-lasting traumatic effects of child sexual abuse on its victims but also brings forth their resistance strategies to cope with the abuse and its aftermath. The domination as a norm becomes vital in the construction of hegemonic masculinity. Thus, resistance to subordination, marginalization becomes counter-hegemonic practice.

\section{References}

Connell, R.W. and James W. Messerschmidt. "Hegemonic Masculinity: Rethinking the Concept." Gender and Society, vol. 19, no. 6, 2005, pp. 829-859.
Connell, R.W. Gender and Power: Society, the Person and Sexual Politics, Stanford University Press, 1987.

Ghaill, Mairtin. Understanding Masculinities: Social Relations and Cultural Arenas, Open University Press, 1996.

Khan-Abdullah, N. Male Rape: The Emergence of a Social and Legal Issue, Palgrave Macmillan, 2008.

Messerschmidt, J.W. Masculinities in the Making: From the Local to the Global, Rowman \& Littlefield, 2015.

Messerschmidt, J.W. "Masculinities and Femicide." Qualitative Sociology Review, vol. 13, no. 3, 2017, pp. 70-79.

Sandhu, Amandeep. Roll of Honour, Rupa Publications, 2012.

Westwood, Sallie. "Feckless Fathers: Masculinities and the British State." Understanding Masculinities: Social Relations and Cultural Arenas, edited by Mairtin, M., Open University Press, 1996, pp. 21-34.

Wolpe, A.M. Within School Walls: The Role of Discipline, Sexuality and the Curriculum, Routledge, 1988.

\section{Author Details}

Jaspreet Singh, Research Scholar, Department of English, School of Humanities and Languages, Central University of Himachal Pradesh, Dharamshala, Himachal Pradesh, India.Email ID: jaspreetsivian87@gmail.com. 